for conservation globally

Threatened

通
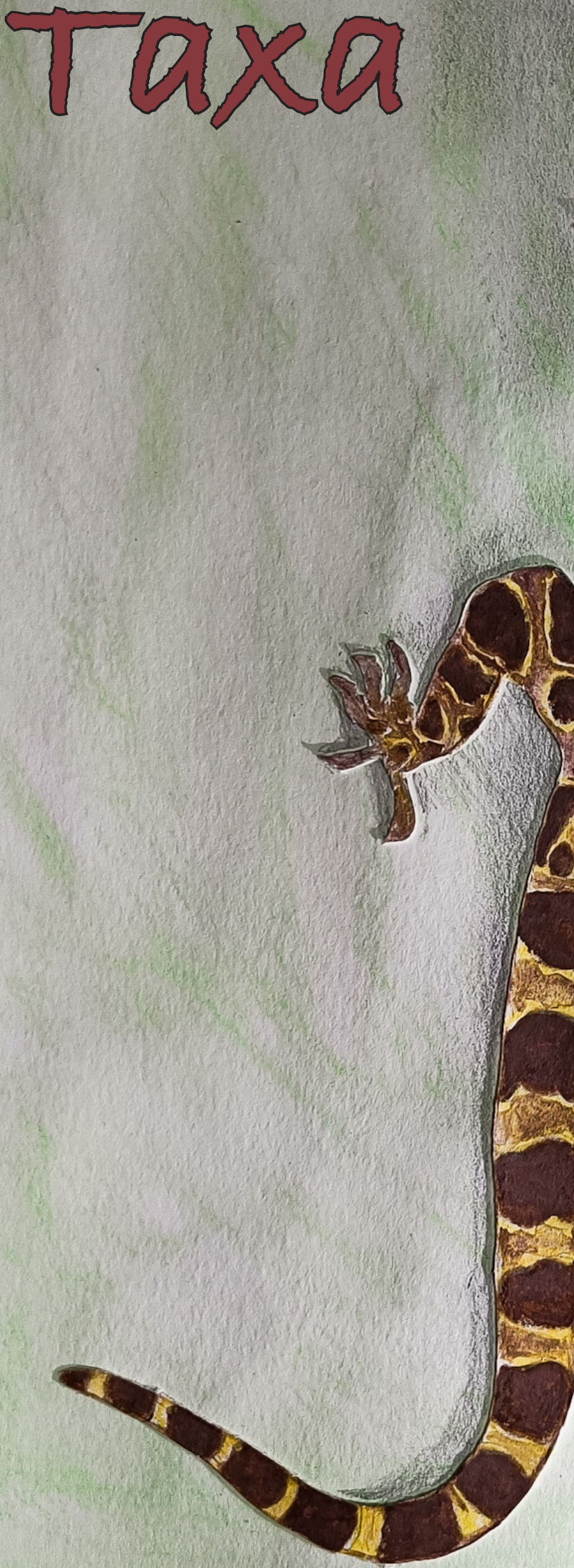

Open Access

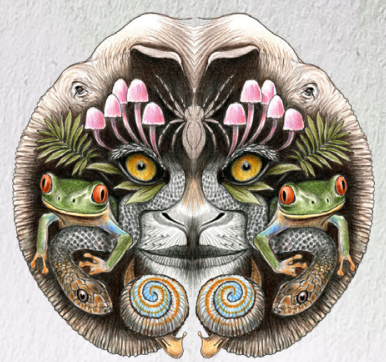

$10.1160 \mathrm{~g} / \mathrm{j}$ ott.2022.14.1.20311-20538 wWw.threatenedtaxa.org

26 January 2022 (Online \& Print) 14(1): 20311-20538 ISSN0974-7907 (Online) ISSN 0974-7893 (Print) 


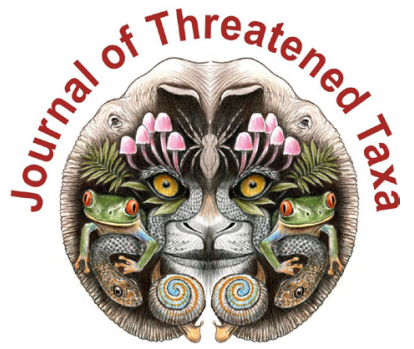

ISSN 0974-7907 (Online); ISSN $0974-7893$ (Print)

Publisher

Host

Wildlife Information Liaison Development Society

www.wild.zooreach.org

Zoo Outreach Organization www.zooreach.org

No. 12, Thiruvannamalai Nagar, Saravanampatti - Kalapatti Road, Saravanampatti, Coimbatore, Tamil Nadu 641035, India

Ph: +91 9385339863 | www.threatenedtaxa.org

Email: sanjay@threatenedtaxa.org

EDITORS

\section{Founder \& Chief Editor}

Dr. Sanjay Molur

Wildlife Information Liaison Development (WILD) Society \& Zoo Outreach Organization (ZOO),

12 Thiruvannamalai Nagar, Saravanampatti, Coimbatore, Tamil Nadu 641035, India

\section{Deputy Chief Editor}

Dr. Neelesh Dahanukar

Noida, Uttar Pradesh, India

\section{Managing Editor}

Mr. B. Ravichandran, WILD/ZOO, Coimbatore, India

\section{Associate Editors}

Dr. Mandar Paingankar, Government Science College Gadchiroli, Maharashtra 442605, India

Dr. Ulrike Streicher, Wildlife Veterinarian, Eugene, Oregon, USA

Ms. Priyanka Iyer, ZOO/WILD, Coimbatore, Tamil Nadu 641035, India

Dr. B.A. Daniel, ZOO/WILD, Coimbatore, Tamil Nadu 641035, India

\section{Editorial Board}

Dr. Russel Mittermeier

Executive Vice Chair, Conservation International, Arlington, Virginia 22202, USA

\section{Prof. Mewa Singh Ph.D., FASc, FNA, FNASc, FNAPsy}

Ramanna Fellow and Life-Long Distinguished Professor, Biopsychology Laboratory, and Institute of Excellence, University of Mysore, Mysuru, Karnataka 570006, India; Honorary Professor, Jawaharlal Nehru Centre for Advanced Scientific Research, Bangalore; and Adjunct Professor, National Institute of Advanced Studies, Bangalore

\section{Stephen D. Nash}

Scientific Illustrator, Conservation International, Dept. of Anatomical Sciences, Health Sciences Center, T-8, Room 045, Stony Brook University, Stony Brook, NY 11794-8081, USA

\section{Dr. Fred Pluthero}

Toronto, Canada

\section{Dr. Priya Davidar}

Sigur Nature Trust, Chadapatti, Mavinhalla PO, Nilgiris, Tamil Nadu 643223, India

\section{Dr. Martin Fisher}

Senior Associate Professor, Battcock Centre for Experimental Astrophysics, Cavendish

Laboratory, JJ Thomson Avenue, Cambridge CB3 OHE, UK

\section{Dr. John Fellowes}

Honorary Assistant Professor, The Kadoorie Institute, 8/F, T.T. Tsui Building, The University of Hong Kong, Pokfulam Road, Hong Kong

\section{Prof. Dr. Mirco Solé}

Universidade Estadual de Santa Cruz, Departamento de Ciências Biológicas, Vice-coordenado do Programa de Pós-Graduação em Zoologia, Rodovia Ilhéus/Itabuna, Km 16 (45662-000)

Salobrinho, Ilhéus - Bahia - Brasil

\section{Dr. Rajeev Raghavan}

Professor of Taxonomy, Kerala University of Fisheries \& Ocean Studies, Kochi, Kerala, India

\section{English Editors}

Mrs. Mira Bhojwani, Pune, India

Dr. Fred Pluthero, Toronto, Canad

Mr. P. Ilangovan, Chennai, India

Web Development

Mrs. Latha G. Ravikumar, ZOO/WILD, Coimbatore, India

\section{Typesetting}

Mr. Arul Jagadish, ZOO, Coimbatore, India

Mrs. Radhika, ZOO, Coimbatore, India

Mrs. Geetha, ZOO, Coimbatore India
Fundraising/Communications

Mrs. Payal B. Molur, Coimbatore, India

Subject Editors 2018-2020

Fungi

Dr. B. Shivaraju, Bengaluru, Karnataka, India

Dr. R.K. Verma, Tropical Forest Research Institute, Jabalpur, India

Dr. Vatsavaya S. Raju, Kakatiay University, Warangal, Andhra Pradesh, India

Dr. M. Krishnappa, Jnana Sahyadri, Kuvempu University, Shimoga, Karnataka, India

Dr. K.R. Sridhar, Mangalore University, Mangalagangotri, Mangalore, Karnataka, India

Dr. Gunjan Biswas, Vidyasagar University, Midnapore, West Bengal, India

\section{Plants}

Dr. G.P. Sinha, Botanical Survey of India, Allahabad, India

Dr. N.P. Balakrishnan, Ret. Joint Director, BSI, Coimbatore, India

Dr. Shonil Bhagwat, Open University and University of Oxford, UK

Prof. D.J. Bhat, Retd. Professor, Goa University, Goa, India

Dr. Ferdinando Boero, Università del Salento, Lecce, Italy

Dr. Dale R. Calder, Royal Ontaro Museum, Toronto, Ontario, Canada

Dr. Cleofas Cervancia, Univ. of Philippines Los Baños College Laguna, Philippines

Dr. F.B. Vincent Florens, University of Mauritius, Mauritius

Dr. Merlin Franco, Curtin University, Malaysia

Dr. V. Irudayaraj, St. Xavier's College, Palayamkottai, Tamil Nadu, India

Dr. B.S. Kholia, Botanical Survey of India, Gangtok, Sikkim, India

Dr. Pankaj Kumar, Kadoorie Farm and Botanic Garden Corporation, Hong Kong S.A.R., China

Dr. V. Sampath Kumar, Botanical Survey of India, Howrah, West Bengal, India

Dr. A.J. Solomon Raju, Andhra University, Visakhapatnam, India

Dr. Vijayasankar Raman, University of Mississippi, USA

Dr. B. Ravi Prasad Rao, Sri Krishnadevaraya University, Anantpur, India

Dr. K. Ravikumar, FRLHT, Bengaluru, Karnataka, India

Dr. Aparna Watve, Pune, Maharashtra, India

Dr. Qiang Liu, Xishuangbanna Tropical Botanical Garden, Yunnan, China

Dr. Noor Azhar Mohamed Shazili, Universiti Malaysia Terengganu, Kuala Terengganu, Malaysia

Dr. M.K. Vasudeva Rao, Shiv Ranjani Housing Society, Pune, Maharashtra, India

Prof. A.J. Solomon Raju, Andhra University, Visakhapatnam, India

Dr. Mandar Datar, Agharkar Research Institute, Pune, Maharashtra, India

Dr. M.K. Janarthanam, Goa University, Goa, India

Dr. K. Karthigeyan, Botanical Survey of India, India

Dr. Errol Vela, University of Montpellier, Montpellier, France

Dr. P. Lakshminarasimhan, Botanical Survey of India, Howrah, India

Dr. Larry R. Noblick, Montgomery Botanical Center, Miami, USA

Dr. K. Haridasan, Pallavur, Palakkad District, Kerala, India

Dr. Analinda Manila-Fajard, University of the Philippines Los Banos, Laguna, Philippines

Dr. P.A. Sinu, Central University of Kerala, Kasaragod, Kerala, India

Dr. Afroz Alam, Banasthali Vidyapith (accredited A grade by NAAC), Rajasthan, India

Dr. K.P. Rajesh, Zamorin's Guruvayurappan College, GA College PO, Kozhikode, Kerala, India

Dr. David E. Boufford, Harvard University Herbaria, Cambridge, MA 02138-2020, USA

Dr. Ritesh Kumar Choudhary, Agharkar Research Institute, Pune, Maharashtra, India

Dr. Navendu Page, Wildlife Institute of India, Chandrabani, Dehradun, Uttarakhand, India

\section{Invertebrates}

Dr. R.K. Avasthi, Rohtak University, Haryana, India

Dr. D.B. Bastawade, Maharashtra, India

Dr. Partha Pratim Bhattacharjee, Tripura University, Suryamaninagar, India

Dr. Kailash Chandra, Zoological Survey of India, Jabalpur, Madhya Pradesh, India

Dr. Ansie Dippenaar-Schoeman, University of Pretoria, Queenswood, South Africa

Dr. Rory Dow, National Museum of natural History Naturalis, The Netherlands

Dr. Brian Fisher, California Academy of Sciences, USA

Dr. Richard Gallon, llandudno, North Wales, LL30 1UP

Dr. Hemant V. Ghate, Modern College, Pune, India

Dr. M. Monwar Hossain, Jahangirnagar University, Dhaka, Bangladesh

Mr. Jatishwor Singh Irungbam, Biology Centre CAS, Branišovská, Czech Republic.

Dr. Ian J. Kitching, Natural History Museum, Cromwell Road, UK

Dr. George Mathew, Kerala Forest Research Institute, Peechi, India

For Focus, Scope, Aims, and Policies, visit https://threatenedtaxa.org/index.php/JoTT/aims_scope
For Article Submission Guidelines, visit https://threatenedtaxa.org/index.php/JoTT/about/submissions
For Policies against Scientific Misconduct, visit https://threatenedtaxa.org/index.php/JoTT/policies_various

continued on the back inside cover 


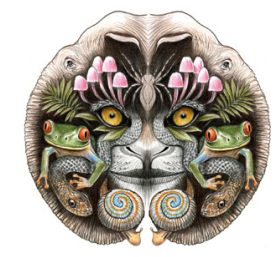

\title{
Morphological characterization and mt DNA barcode of a tiger moth species, Asota ficus (Fabricius, 1775) (Lepidoptera: Noctuoidea: Erebidae: Aganainae) from India
}

\author{
Aparna Sureshchandra Kalawate ${ }^{1}$ (D) K.P. Dinesh ${ }^{2}$ (D) \& A. Shabnam ${ }^{3}$ (D) \\ 1,2,3 Zoological Survey of India, Western Regional Centre, Vidya Nagar, Sector-29, P.C.N.T. (PO), Rawet Road, Akurdi, Pune, \\ Maharashtra 411044, India \\ ${ }^{1}$ devarpanento@gmail.com (corresponding author), ${ }^{2}$ kpdinesh.zsi@gmail.com, ${ }^{3}$ shabnamansari9113@gmail.com
}

\begin{abstract}
The members of the genus Asota are widely distributed from Africa, India, Sri Lanka, Myanmar, and Malayan regions to the Australian region containing 55 described species. Asota ficus (Fabricius, 1775) is one among the nine species of the genus described from India having a wide range of distribution. The present study includes the first mitochondrial DNA barcode generated from India for $A$. ficus with a valid voucher describing external morphological characters together with the male and female genitalia. Discussions pertain to the utility of DNA barcodes for studies on moths in India with a comment on the identity of other sequences showing shallow genetic divergence with our sequences.
\end{abstract}

Keywords: Arctiinae, Ficus, genitalia study, Hypsa, Lepidopterism, Maharashtra, Mitragyna, molecular study, mt COI, Ricinus.

The subfamily Aganainae Boisduval, 1833 was earlier considered as family Aganaidae or Hypsidae (Inoue et al 1982). Later studies considered it as subfamily Hypsinae of Arctiidae (Seitz 1914; Daniel 1943) or subfamily Aganainae of Noctuidae (Holloway 1988; Scoble 1992; Kitching \& Rawlins 1998). Until molecular studies, the familial position was unstable, later on phylogenetic studies placed the subfamily Aganainae under the family Erebidae (Fibiger \& Lafontaine 2005; Zahiri et al. 2012).
Aganainae includes 109 species of 11 genera worldwide (Zahiri et al. 2012; Bayarsaikhan et al. 2016).

Many Aganainae moths are large, brightly coloured, aposematic, with bare lower frons and long upturned labial palps having long and slender third segment; vein $\mathrm{M} 2$ in forewing arises closer to the origin of $\mathrm{M} 3$ than $\mathrm{M} 1$, in the lower part of the discal cell; $\mathrm{Cu}$ appearing four-branched; vein $\mathrm{M} 2$ in the hindwing is present so Cu appears four-branched (Holloway 1988; Zahiri et al. 2012). The larvae have single subventral seta on the mesothoracic and metathoracic segments. The subfamily exhibits a sister relationship with Arctiinae with a strongly supported pairing (Zahiri et al 2011).

Moths from this subfamily are pests on plant species of Apocynaceae, Asclepiadaceae, Moraceae (Holloway 1988; Common 1990; Bayarsaikhan et al. 2016), and lactiferous families that contain cardenolides (Bayarsaikhan et al. 2016). They feed on poisonous plants, and hence are often aposematic day flyers (Kitching \& Rawlins 1998; Bayarsaikhan et al. 2016).

The genus Asota Hübner, [1819] was erected by Jacob

Copyright: (C) Kalawate et al. 2022. Creative Commons Attribution 4.0 International License. JoTT allows unrestricted use, reproduction, and distribution of this article in any medium by providing adequate credit to the author(s) and the source of publication.

Funding: The work is based on the annual research programme of Zoological Survey of India, WRC, Pune ( Ministry of Environment \& Forests, Govt. of India).

Competing interests: The authors declare no competing interests.

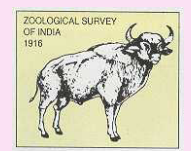

Acknowledgements: Authors are grateful to the director, Zoological Survey of India, Kolkata and the officer-in-charge, Zoological Survey of India, Western Regional Centre, Pune for encouragement and research facilities. We are grateful to Dr. R.M. Sharma, retired scientist and the officer-in-charge, Zoological Survey of India, Western Regional Centre, Pune for critically going through the manuscript. Due acknowledgements to the survey team members of Zoological Survey of India, Western Regional Centre, Pune for collection efforts. The help of Ms. Mehrun Raje in the wet lab studies are acknowledged. Authors are thankful to the anonymous reviewers and the subject editor for their valuable suggestions and constructive criticism on the earlier version of the manuscript. 
Hubner in 1819 considering Phalaena javana (Cramer, [1780]) from Java as type species. So far, 55 species are known from this genus including nine from India. The Asota species reported from India are: caricae (Fabricius, 1775); plana (Walker, 1854); canaraica (Moore, 1878); egens (Walker, 1854); ficus (Fabricius, 1775); heliconia (Linnaeus, 1758); paphos (Fabricius, 1787); producta (Butler, 1875); sericea (Moore, 1878). A. ficus was placed under the genus Hypsa as Hypsa ficus by Hampson (1892) under the family Hypsidae: section-II. Hampson (1892) divided the genus Hypsa under two sections on the basis of structure of antennae. In Section-I the antennae of males are fasciculated with short cilia. The fasciculated male antennae, long cilia and the long $3^{\text {rd }}$ segment of palpi forms the section-II. Caterpillar of $A$. ficus is recorded feeding mainly on castor and ficus.

The genus Asota is responsible for Lepidopterism, a disease caused by the adult or the caterpillar of moths or butterflies (Wills et al. 2016). In Kerala India, it was reportedly caused by the tiger moth $A$. caricae (Anonymous 2016). The fever caused by Lepidopterism mimics the symptoms of the mosquito borne infectious diseases like chikungunya and dengue. The adult moths, while emerging from the pupae, extricate the scales on their body and secretes fluids (Anonymous 2016) which lead to the high fever either when in contact with the human skin or due to inhalation. As per Wills et al. (2016), allergic reactions are due to the presence of poisonous chemicals like histamines, imidazole and peptides.

DNA barcoding is a quick and reliable nucleotidebased identification technique across the animal kingdom, founded on the mitochondrial Cytochrome oxidase I gene ( $\mathrm{mt}$ COI) by Hebert's group in 2003. The ability of $\mathrm{COI}$ sequences to discriminate closely allied species based on restricted intraspecific mitochondrial DNA divergence and utilizing it as an aid to resolve the alpha diversity of species in diverse taxonomic groups including Lepidoptera has been validated (Hebert et al. 2003b). These species-specific signatures, identified as DNA barcodes help to delimit the problematic taxa (Hebert et al. 2003a) also in cases where identification is not possible with the traditional taxonomic techniques alone. DNA barcode not only provides a boon to taxonomic research but also serves as a form of comprehensive, widely accessible system for identification and validation of species. Hence, in the present study an attempt has been made to develop a DNA barcode for the species $A$. ficus from Maharashtra along with its morphological description (adult together with external genitalia); the utility of mt DNA barcodes in the Indian moth studies are discussed.

\section{MATERIALS AND METHODS}

Moth specimens were collected using a light trap having mercury vapour lamp as a light source of $160 \mathrm{~W}$. It was hung in the middle of the white sheet installed in the field during the night. Moth specimens that were captured were euthanized by ethyl acetate vapours. Then they were transported to the laboratory in insect packets (made of butter paper) for further analysis.

In the laboratory, the specimens were stretched, pinned and stored in entomological boxes filled with preservatives. For morphological studies the specimens were studied under Leica EZ4E stereomicroscope. The map of the collection locality was prepared using open free QGIS software. The details of the collection locality are given under the material examined and is also shown in Figure 1. Identification of the specimens was done as per Hampson (1892). Male and female genitalia were studied following Robinson (1976). The identified specimens are deposited at the National Zoological Collections of the Zoological Survey of India, Western Regional Centre, Pune, Maharashtra, India (ZSI/WRC).

DNA extraction was performed using DNeasy blood and tissue kit (Qiagen) using leg and abdomen of a dried specimen. DNA quantitation was performed by HS dsDNA assay kit on Qubit 2.0 fluorometer. Mitochondrial $\mathrm{COI}$ (mt COI) gene was amplified using universal primer pair, LCO1490 and HCO2198 (Folmer et al. 1994) in 25 $\mu \mathrm{L}$ reaction volume constituted by $12.5 \mu \mathrm{L}$ of Master Mix (Promega), $10 \mathrm{pmol}$ of each forward and reverse primer, 50 ng of template DNA along with Nuclease free water up to Q.S. Thermal cycling profile performed as per Kalawate et al. (2020a). Amplification of the desired gene was confirmed by gel electrophoresis stained by SYBR safe DNA gel stain (Invitrogen), visualized under UV by gel documentation system. Purification of the amplified product was done by Invitrogen's Pure Link PCR Purification Kit. The purified PCR product was sequenced bi-directionally by Sanger's method on $A B I$ 377 (Applied Biosciences) sequencer.

Both the forward and reverse sequences generated in the current studies were verified manually for corrections. Initially $838 \mathrm{mt} \mathrm{COI}$ gene sequences available for the genus Asota were downloaded from the GenBank and were aligned using MEGA 5.2 software (Tamura et al 2011). MEGA 5.2 (Tamura et al. 2013) was used for calculating uncorrected pairwise genetic distances. Initial tree was built (using MEGA 5.2) including all reported species with molecular data for the genus Asota, comprising 235 sequences excluding identical sequences from the same locality for a single species/subspecies. Since $\mathrm{mt} \mathrm{COI}$ is not a good candidate 


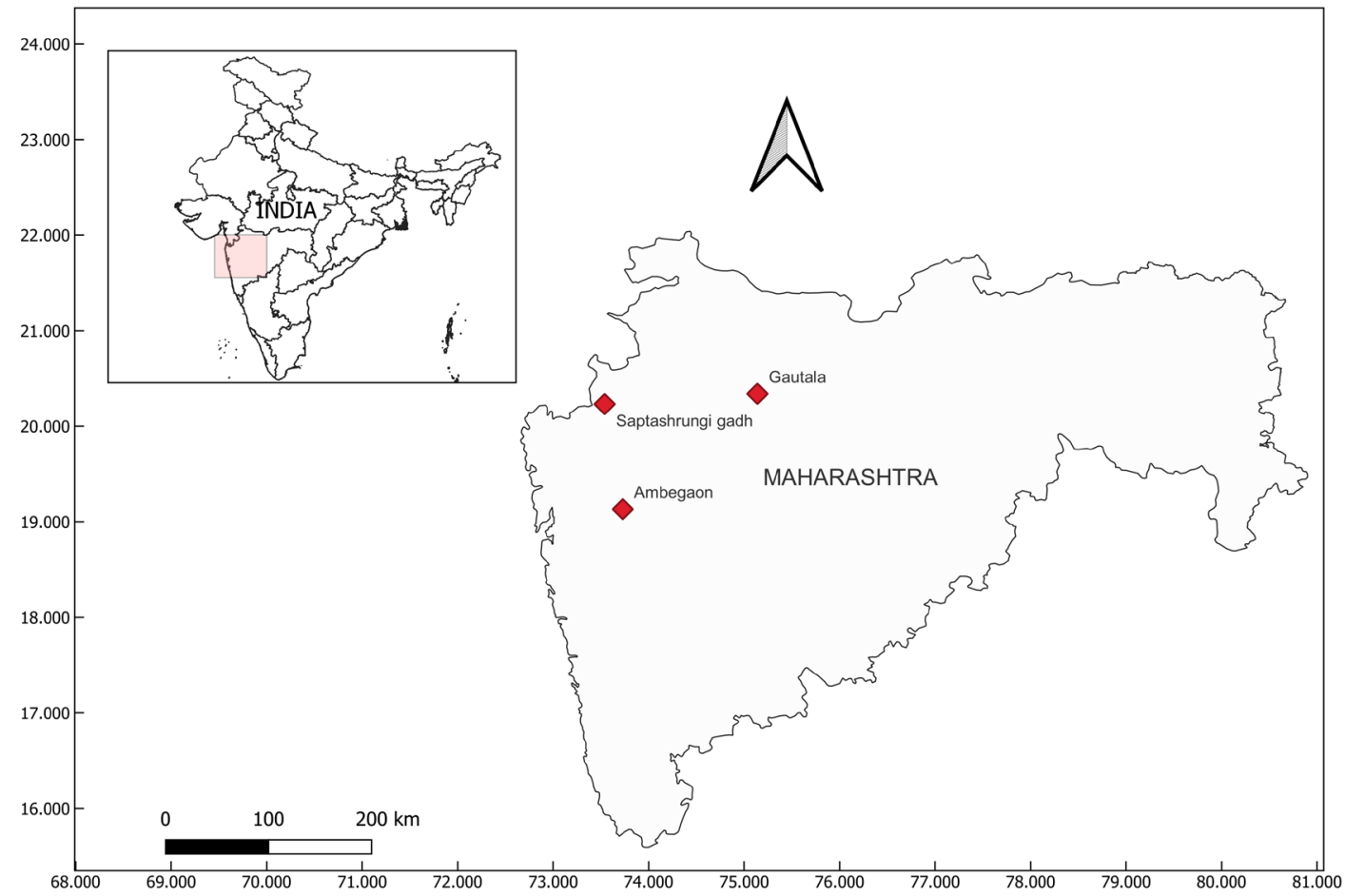

Figure 1. Collection localities of Asota ficus from Maharashtra, India.

gene for phylogenetic studies (Cameron et al. 2004; Lafontaine \& Schmidt 2010) and our initial single gene phylogenetic tree ended up in polytomies without proper phylogenetic relationships, we considered presenting the phylogenetic tree comprising all the sequences of $A$. ficus available on the GenBank with the sequences generated by us and the probable sister species $A$. speciosa treating species Neochera inops as an outgroup. The phylogenetic inferences drawn are only to show the monophyly of all the sequences of $A$. ficus. Maximum likelihood tree was generated using RaxML (Silvestro \& Michalak 2012) with thorough bootstrap of 1,000 replicates under the GTR+GAMMA+I model and the final consensus tree was visualized by Fig Tree v1.4.0. Sequences generated in the studies are submitted to the GenBank (OL630456.1 \& OL630457.1).

\section{RESULT AND DISCUSSIONS}

Taxonomic account

Superfamily Noctuoidea Latreille, 1809

Family Erebidae Leach, [1815]

Subfamily Aganainae Boisduval, 1833

Genus Asota Hübner, [1819]

Asota Hübner, [1819], Verz. bek. Schmett. (11): 164.

Type Species: Phalaena javana (Cramer, [1780])

\section{Asota ficus (Fabricius, 1775)}

Noctua ficus Fabricius,1775, Syst. Ent.: 595.

Lacides ficus, Moore,188, Lep. Ceylon, 2(1): 53, pl. 100, f. 2.

Hypsa ficus, Hampson,1892, Fauna Brit. India, Moths, 1: 504.

Type Locality. India.

Material examined/source: 01 male, Saptashringigadh, Nashik, Maharashtra, India (20.23N, 73.54E; 1,000 m), 06 November 2016, coll. A.S. Kalawate (ZSI/WRC/L-1482); 01 female, Ambegaon, Pune, Maharashtra, India (19.13N, 73.73E; 730 m), 23 June 2017, coll. A.S. Kalawate \& party (ZSI/WRC/L-1780); 02 male, Bhaskaracharya Forest Rest house, Gautala, Jalgaon, Maharashtra, India (20.34N, 75.14E; $711 \mathrm{~m}$ ), 27 September 2019, coll. P.S. Bhatnagar \& party (ZSI/ WRC/L-2069).

Morphological description: Adult (Image 1A,B). Wing expanse: $55 \mathrm{~mm}$ in male and $63 \mathrm{~mm}$ in female. Antennae of male fasciculated, cilia long; $3^{\text {rd }}$ joint of palpi long, grey in colour, tipped with black. Head, thorax and abdomen orange-yellow; tegulae with yellow base and a black spot. Abdomen with series of black spots. Orange basal patch on forewing extending along costa and in cell to two-third length of cell, an orange spot encircled with black on the costa, and streaks in cell and on inner margin, two black spots on costa and in 

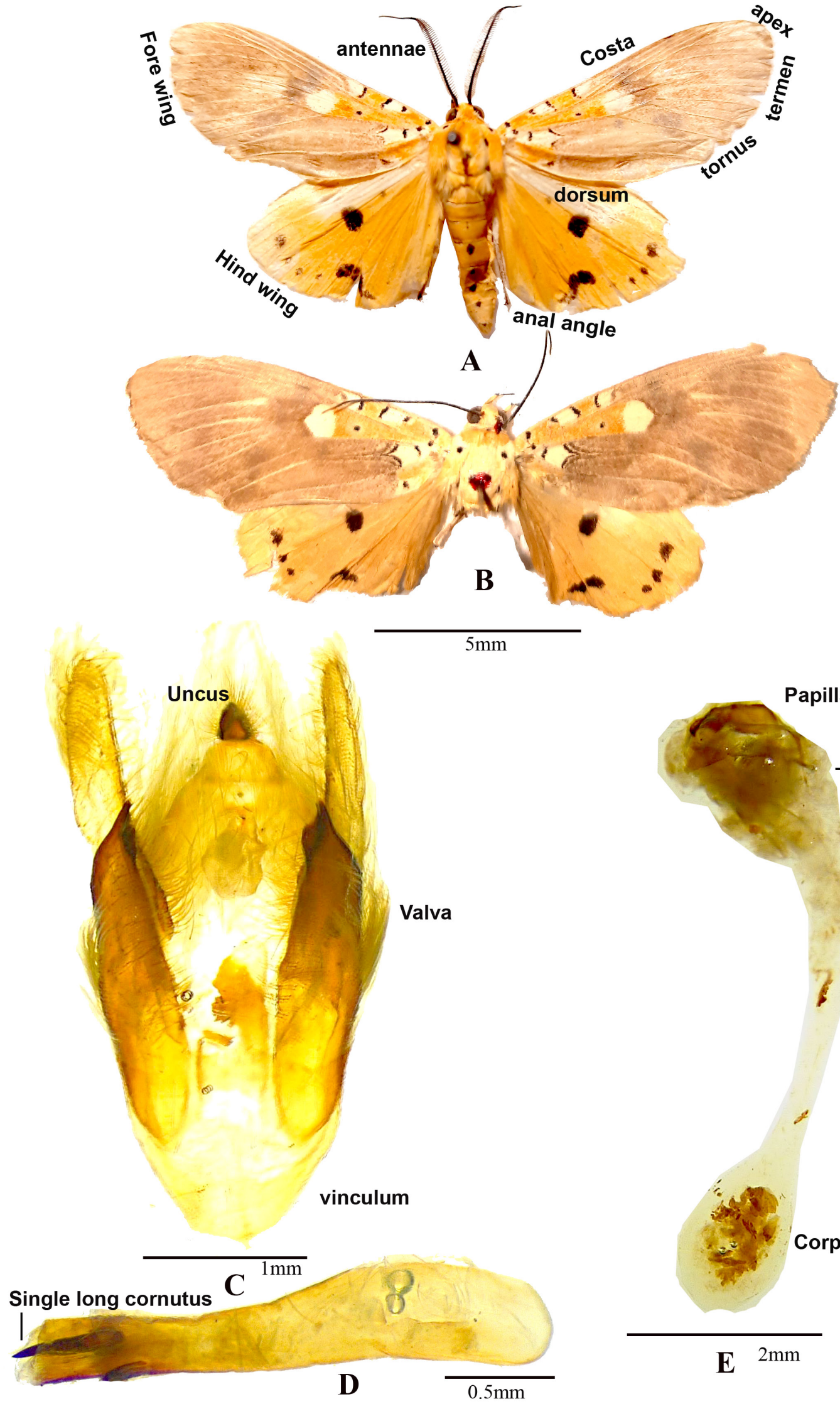

Corpus bursae

Image 1. Asota ficus: A-Male | B-Female | C-Genitalia | D-Aedeagus | E-Female genitalia. 


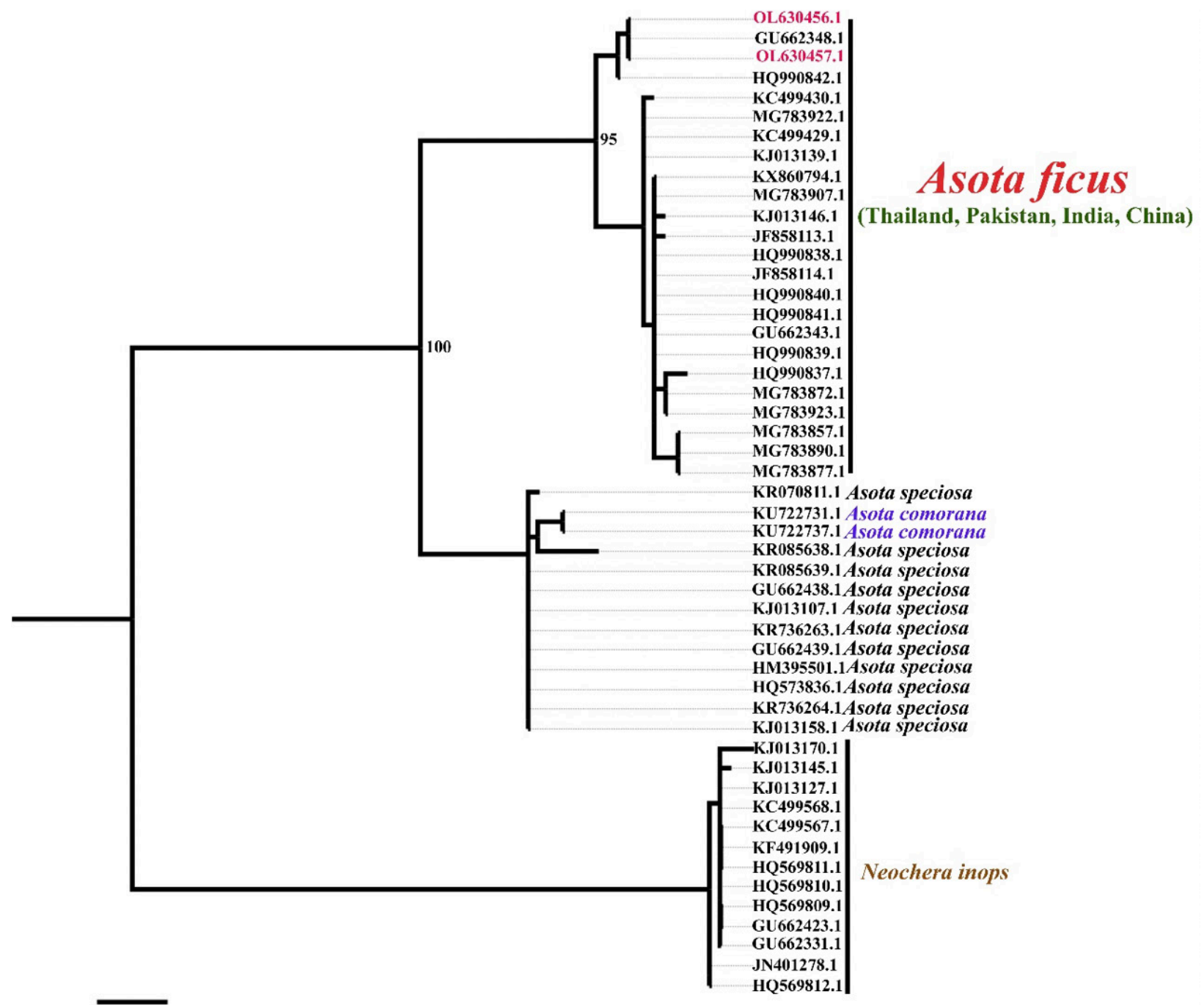

0.06

Figure 2. Maximum likelihood (ML) tree for the species of Asota based on the $578 \mathrm{bp}$ of mitochondrial COI DNA gene sequences.

cell, one on inner margin, and two lines across internomedian interspace; rest of the wing olive-brown, the veins are striped with yellow. Hind wing bright orangeyellow; black spot at end of cell and series of irregular sized and placed black spots at submarginal area. Male and female are similar in external morphology except antennae. In male they are, fasciculated with long cilia and very short cilia in female.

Male genitalia (Image 1C). Uncus long, highly sclerotised broad till middle and then narrowing down, apex pointed recurved. Tegumen longer than the uncus, moderately sclerotised with broad arms, inverted v-shaped; valvae symmetrical, weakly sclerotised, setosed, costa strongly produced into a long process, harpe with a pointed process; vinculum longer than tegumen, u-shaped; juxta elongated; Aedeagus (Image 1D) long, relatively thin, apical portion dentate ventrally.
Vesica membranous with single, long cornutus.

Female genitala (Image 1E). Corpus bursae oblong, membranous; ductus bursae long, membranous; ostium bursae simple, sclerotized; posterior and anterior apophyses are of equal length, sclerotized; papilla analis oval, heavily sclerotized with setae.

Distribution: India (throughout including Maharashtra), China, Japan, Malaysia, Myanmar, Nepal, Sri Lanka, Taiwan, and Thailand.

Host plants. Ricinus communis, Ficus carica, $F$. hispida, F. racemosa, F. pumila, F. infectoria, F. religiosa, and Mitragyna diversifolia (ICAR-NBAIR 2020).

DNA barcode studies: In the GenBank a total of 22 sequences of $\mathrm{mt} \mathrm{COI}$ are available for $A$. ficus (Table 1 ), of which nine sequences are from India. Within India, these sequences are from the states of Assam, Maharashtra and Tamil Nadu (all are unpublished data 
Table 1. Details of the mt COI GenBank accession numbers of Asota utilised in the construction of ML phylogenetic tree.

\begin{tabular}{|c|c|c|c|c|}
\hline & GenBank Accession No. & Locality & Species name as per NCBI & Publication details as per NCBI \\
\hline 1 & GU662348.1 & Thailand: Chiang Mai & Asota ficus & Unpublished \\
\hline 2 & OL630456.1 & India: Maharashtra, Nasik, Saptashrungigadh. & Asota ficus & Current study \\
\hline 3 & OL630457.1 & India: Maharashtra, Jalgaon & Asota ficus & Current study \\
\hline 4 & HQ990842.1 & Pakistan & Asota ficus & Unpublished \\
\hline 5 & KC499430.1 & India: Tamil Nadu, Kalkad & Asota ficus & Unpublished \\
\hline 6 & MG783922.1 & India: Maharashtra & Asota ficus & Unpublished \\
\hline 7 & KC499429.1 & China: Yunnan & Asota ficus & Unpublished \\
\hline 8 & KJ013139.1 & India: Assam, & Asota ficus & Unpublished \\
\hline 9 & KX860794.1 & Pakistan: Punjab & Asota ficus & Ashfaq et al. (2017) \\
\hline 10 & MG783907.1 & India: Maharashtra & Asota ficus & Unpublished \\
\hline 11 & KJ013146.1 & India: Nameri NP & Asota ficus & Unpublished \\
\hline 12 & $J F 858113.1$ & Pakistan & Asota ficus & Unpublished \\
\hline 13 & HQ990838.1 & Pakistan & Asota ficus & Unpublished \\
\hline 14 & JF858114.1 & Pakistan & Asota ficus & Unpublished \\
\hline 15 & HQ990840.1 & Pakistan & Asota ficus & Unpublished \\
\hline 16 & HQ990841.1 & Pakistan & Asota ficus & Unpublished \\
\hline 17 & GU662343.1 & Thailand: Chiang Mai & Asota ficus & Unpublished \\
\hline 18 & HQ990839.1 & Pakistan & Asotaficus & Unpublished \\
\hline 19 & HQ990837.1 & Pakistan & Asota ficus & Unpublished \\
\hline 20 & MG783872.1 & India: Maharashtra & Asota ficus & Unpublished \\
\hline 21 & MG783923.1 & India: Maharashtra & Asota ficus & Unpublished \\
\hline 22 & MG783857.1 & India: Maharashtra & Asota ficus & Unpublished \\
\hline 23 & MG783890.1 & India: Maharashtra & Asota ficus & Unpublished \\
\hline 24 & MG783877.1 & India: Maharashtra & Asota ficus & Unpublished \\
\hline 25 & KR070811.1 & Kenya: Kajiado North & Asota speciosa & Unpublished \\
\hline 26 & KU722731.1 & Comoros: Grande Comore & Asota comorana & Unpublished \\
\hline 27 & KU722737.1 & Comoros: Grande Comore & Asota comorana & Unpublished \\
\hline 28 & KR085638.1 & Zambia: Victoria Falls & Asota speciosa & Unpublished \\
\hline 29 & KR085639.1 & Zambia: Lusaka Ridgeway & Asota speciosa & Unpublished \\
\hline 30 & GU662438.1 & Nigeria: Laeinde & Asota speciosa & Unpublished \\
\hline 31 & KJ013107.1 & Tanzania: Mbizi forest & Asota speciosa & Unpublished \\
\hline 32 & KR736263.1 & Nigeria:Oyo & Asota speciosa & Unpublished \\
\hline 33 & GU662439.1 & Cameroon: North Province & Asota speciosa & Unpublished \\
\hline 34 & HM395501.1 & Gabon: WoleuNamiTchimble & Asota speciosa & Unpublished \\
\hline 35 & HQ573836.1 & Gabon: Ogooue-Ivindo & Asota speciosa & Unpublished \\
\hline 36 & KR736264.1 & Nigeria:Oyo & Asota speciosa & Unpublished \\
\hline 37 & KJ013158.1 & Ethiopia: Arba Minch & Asota speciosa & Unpublished \\
\hline 38 & KJ013170.1 & Laos: Nang Phoa & Neochera inops & Unpublished \\
\hline 39 & KJ013145.1 & Laos: Nang Phoa & Neochera inops & Unpublished \\
\hline 40 & KJ013127.1 & Laos: Namha protected area, & Neochera inops & Unpublished \\
\hline 41 & KC499568.1 & Indonesia: Kalimantan Barat & Neochera inops & Unpublished \\
\hline 42 & KC499567.1 & China: Hainan & Neochera inops & Unpublished \\
\hline 43 & KF491909.1 & Malaysia & Neochera inops & Unpublished \\
\hline 44 & HQ569811.1 & Thailand: Nan & Neochera inops & Unpublished \\
\hline 45 & HQ569810.1 & India: Meghalaya & Neochera inops & Unpublished \\
\hline 46 & HQ569809.1 & VietNam: Tam Dao & Neochera inops & Unpublished \\
\hline 47 & GU662423.1 & Thailand: Chiang Mai & Neochera inops & Unpublished \\
\hline 48 & GU662331.1 & Thailand: Chiang Mai & Neochera inops & Unpublished \\
\hline 49 & JN401278.1 & Japan & Neochera inops & Zahiri et al. (2012) \\
\hline 50 & HQ569812.1 & Malaysia: Sarawak & Neochera inops & Unpublished \\
\hline
\end{tabular}


as per GenBank). The current study forms the first published record of DNA barcode for the species $A$. ficus from India with assigned voucher numbers.

In the preliminary phylogenetic tree generated for the studies, all the mt DNA barcodes formed a monophyletic clade for the species A. ficus (Figure 2) showing genetic distance variance from $0.6 \%$ to $1.3 \%$. The clade comprising $A$. speciosa and $A$. comorana showed sister relationship with the clade of $A$. ficus, wherein genetic distance between the species $A$. ficus and $A$. comorana was $2.9 \%$ and $A$. ficus and $A$. speciose was $3.4 \%$. In the present study $A$. comorana is nested within $A$. speciosa which suggests either one of the species was wrongly identified ending up in mislabelled sequences or synonymy of these two taxa. Further studies are necessary to resolve the identity and validity of the species $A$. comorana as the genetic distance between the species $A$. speciosa and $A$. comorana is too shallow (0.6-1.7\%).

Evolutionary distances are fundamental in molecular reconstructions including phylogenetic analysis (Nei \& Kumar 2000). The nucleotide substitution method is widely used to calculate a reliable genetic difference between pairs of sequences (Nei \& Kumar 2000). Since there are limitations with the $\mathrm{mt}$ COI gene (Cameron et al. 2004; Hebert \& Gregory 2005; Lafontaine \& Schmidt 2010), we suggest further studies to comment on the phylogenetic relationships among the species of the genus Asota. Nuclear DNA (n DNA) studies are advocated (Zahiri et al. 2012) to study ancient evolutionary divergence for resolving deeper nodes above species level, having slower mutation rate than mt DNA.

In India, generation of mt COI DNA barcodes for moths is still in a stage of infancy. Recently, Kalawate et al (2020a) have reported the palearctic moth species Olepa schleini Witt et al. 2005 from India with a description of subspecies based on the DNA barcode studies and morphological variations. Additionally, Kalawate et al. (2020b) described three new species along with a subspecies and provided the description of multiple morphotypes of Olepa from India. These studies clearly endorse the utility of DNA barcodes in identification of palearctic species from India (Kalawate et al. 2020a). This technique further avoids taxonomic inflation by describing morphologically different looking morphotypes as a new species (Kalawate et al. 2020b). Further, DNA barcode studies are expected to alleviate identification of morphologically variant species and uncover the cryptic diversity prevailing within the taxonomic groups. Multigene phylogenetic analysis is warranted to decipher the phylogenetic relationships across the members of the family which are wide spread in distribution range.

\section{REFERENCES}

Anonymous (2016). Alert issued for fever caused by tiger moth. http://timesofindia.indiatimes.com/articleshow/51869389. cms?utm_source=contentofinterest\&utm_medium =text\&utm campaign=cppst assessed 01.12.2020.

Ashfaq, M., S. Akhtar, M.A. Rafi, S. Mansoor \& P.D. Hebert (2017). Mapping global biodiversity connections with DNA barcodes: Lepidoptera of Pakistan. PLOS ONE 12(3): e0174749. https://doi. org/10.1371/journal.pone.0174749

Bayarsaikhan, U., N. Sol-Moon \& B. Yang-Seop (2016). Review of the subfamily Aganainae (Lepidoptera, Erebidae) from Cambodia. Journal of Asia-Pacific Biodiversity 9(2): 219-229. https://doi. org/10.1016/j.japb.2016.02.010

Cameron, S.L., K.B. Miller, C.A. D'Haese, M.F. Whiting \& S.C. Barker (2004). Mitochondrial genome data alone are not enough to unambiguously resolve the relationships of Entognatha, Insecta and Crustacea sensu lato (Arthropoda). Cladistics 20(6): 534557. https://doi.org/10.1111/j.1096-0031.2004.00040.x

Common, I.F.B. (1990). Moths of Australia. E.J. Brill and Melbourne University Press, New York.128 pp.

Daniel, F. (1943). Beiträge zur Kenntnis der Arctiidae Ostasiens unter besonderer Berücksichtigung der Ausbeuten $\mathrm{H}$. Höne's aus diesem Gebiet (Lep. Het.). II Teil. Hypsinae, Micrarctiinae, Spilosominae, Arctiinae. Mitteilungen der München Entomologischen Gesellschft 33: 673-759.

Fibiger, M. \& J.D. Lafontaine (2005). A review of the higher classification of the Noctuoidea (Lepidoptera) with special reference to the Holarctic fauna. Esperiana 11: 7-92.

Folmer, O., W.R. Hoeh, M.B. Black \& R.C. Vrijenhoek (1994). Conserved primers for PCR amplification of mitochondrial DNA from different invertebrate phyla. Molecular Marine Biology and Biotechnology 3(5): 294-299.

Hampson, G.F. (1892). The fauna of British India including Ceylon and Burma, Moths - Volume 1. Taylor and Francis, London, 504 pp.

Hebert, P.D., S. Ratnasingham \& J.R. deWaard (2003a). Barcoding animal life: cytochrome c oxidase subunit 1 divergences among closely related species. Proceedings Biological sciences 270 (Suppl. 1): S96-S99. https://doi.org/10.1098/rsbl.2003.0025

Hebert, P.D., A. Cywinska, S.L. Ball \& J.R. deWaard (2003b). Biological identifications through DNA barcodes. Proceedings Biological Sciences 270(1512): 313-21. https://doi.org/10.1098/ rspb.2002.2218

Hebert, P.D.N. \& T.R. Gregory (2005). The promise of DNA barcoding for taxonomy. Systematic Biology 54 (5): 852-859. https://doi. org/10.1080/10635150500354886

Holloway, J.D. (1988). The Moths of Borneo, part. 6: family Arctiidae, subfamilies Syntominae, Euchromiinae, Arctiinae; Noctuidae misplaced in Arctiidae (Camptoloma, Aganaidae). SouthdeneSdnBhd, Kuala Lumpur.

ICAR-NBAIR (2020). Asota ficus. https://www.nbair.res. in/Databases/Databases/insectpests/Asota-caricae php $+\& c d=12 \& h l=e n \& c t=c l n k \& g l=i n$ accessed 08.xii.2020.

Inoue, H., S. Sugi, H. Kuroko, A. Kawabe \& M. Owada (1982). Moths of Japan. Kodansha, Tokyo, 344-405 pp.

Kalawate, A.S., S. Pawara, A. Shabnam \& K.P. Dinesh (2020a). DNA barcode reveals the occurrence of Palearctic Olepas chleini Witt et al., 2005 (Lepidoptera: Erebidae: Arctiinae) from peninsular India with morphological variations and a new subspecies. Journal of Threatened Taxa 12(9): 16143-16152. https://doi.org/10.11609/ jot.5596.12.9.16143-16152

Kalawate, A.S., K.P. Dinesh \& A. Shabnam (2020b). DNA barcoding unravels three new species and a subspecies of Olepa Watson, 1980 (Lepidoptera, Erebidae, Arctiinae) from India, with 
morphotypes. Journal of Insect Biodiversity 19(2): 44-60. https:// doi.org/10.12976/jib/2020.19.2.2

Kitching, I.J. \& J. Rawlins (1998). The Noctuoidea, pp. 355-401. Kristensen, N.P. (ed.). Handbook of Zoology, Lepidoptera, Moths and Butterflies, Vol. 1. Evolution, Systematics, and Biogeography. W. de Gruyter, Berlin.

Lafontaine, J.D. \& B.C. Schmidt (2010). Annotated check list of the Noctuoidea (Insecta, Lepidoptera) of North America north of Mexico. ZooKeys 40: 1-239. https://doi.org/10.3897/zookeys.40.414

Nei, M. \& S. Kumar (2000). Molecular Evolution and Phylogenetics. Oxford University Press, $333 \mathrm{pp}$.

Robinson, G.S. (1976). The preparation of slides of Lepidoptera genitalia with special reference to the Microlepidoptera. Entomologist's Gazette 27(2): 127-132.

Scoble, M.J. (1992). The Lepidoptera. Form, Function and Diversity. Oxford University Press, Oxford, 404 pp.

Seitz, A. (1914). The Macrolepidoptera of the world. II. Division Fauna Exotica, A. Kernen, Stuttgart, 10: 105-290 (Bombyces and Sphinges of the Indo-Australian Region). https://doi.org/10.5962/ bhl.title.9400
Silvestro, D. \& I. Michalak (2012). raxmIGUI: a graphical front-end for RAxML. Organisms Diversity \& Evolution 12(4): 335-337.

Tamura, K., D. Peterson, N. Peterson, G. Stecher, M. Nei \& S. Kumar (2011). MEGA5: Molecular Evolutonary Genetics Analysis using Maximum Likelihood, Evolutionary Distance and Maximum Parsimony Methods. Molecular Biology and Evolution 28(10): 2731-2739. htps://doi.org/10.1093/molbev/msr121

Wills, P.J., M. Anjana, M. Nitin, R. Varun, P. Sachidanandan, T.M. Jacob, L. Madhavan, R.V. Thampah \& K.K. Varma (2016). Population explosions of Tiger Moth lead to Lepidopterism mimicking infectious fever outbreaks. PLoS ONE 11(4): e0152787. https://doi. org/10.1371/journal.pone.0152787

Zahiri, R., I.J. Kitching, J.D. Lafontaine, M. Mutanen, L. Kaila, J.D. Holloway \& N. Wahlberg (2011). A new molecular phylogeny offers hope for a stable family level classification of the Noctuoidea (Lepidoptera). Zoologica Scripta 40(2): 158-173.

Zahiri, R., J.D. Holloway, I.J. Kitching, J.D. Lafontaine, M. Mutanen, \& N. Wahlberg (2012). Molecular phylogenetics of Erebidae (Lepidoptera, Noctuoidea). Systematic Entomology 37(1): 102-124. htps://doi.org/doi:10.1111/j.1365-3113.2011.00607.x 
Dr. John Noyes, Natural History Museum, London, UK

Dr. Albert G. Orr, Griffith University, Nathan, Australia

Dr. Sameer Padhye, Katholieke Universiteit Leuven, Belgium

Dr. Nancy van der Poorten, Toronto, Canada

Dr. Kareen Schnabel, NIWA, Wellington, New Zealand

Dr. R.M. Sharma, (Retd.) Scientist, Zoological Survey of India, Pune, India

Dr. Manju Siliwal, WILD, Coimbatore, Tamil Nadu, India

Dr. G.P. Sinha, Botanical Survey of India, Allahabad, India

Dr. K.A. Subramanian, Zoological Survey of India, New Alipore, Kolkata, India

Dr. P.M. Sureshan, Zoological Survey of India, Kozhikode, Kerala, India

Dr. R. Varatharajan, Manipur University, Imphal, Manipur, India

Dr. Eduard Vives, Museu de Ciències Naturals de Barcelona, Terrassa, Spain

Dr. James Young, Hong Kong Lepidopterists' Society, Hong Kong

Dr. R. Sundararaj, Institute of Wood Science \& Technology, Bengaluru, India

Dr. M. Nithyanandan, Environmental Department, La Ala Al Kuwait Real Estate. Co. K.S.C.,

Kuwait

Dr. Himender Bharti, Punjabi University, Punjab, India

Mr. Purnendu Roy, London, UK

Dr. Saito Motoki, The Butterfly Society of Japan, Tokyo, Japan

Dr. Sanjay Sondhi, TITLI TRUST, Kalpavriksh, Dehradun, India

Dr. Nguyen Thi Phuong Lien, Vietnam Academy of Science and Technology, Hanoi, Vietnam

Dr. Nitin Kulkarni, Tropical Research Institute, Jabalpur, India

Dr. Robin Wen Jiang Ngiam, National Parks Board, Singapore

Dr. Lional Monod, Natural History Museum of Geneva, Genève, Switzerland.

Dr. Asheesh Shivam, Nehru Gram Bharti University, Allahabad, India

Dr. Rosana Moreira da Rocha, Universidade Federal do Paraná, Curitiba, Brasi

Dr. Kurt R. Arnold, North Dakota State University, Saxony, Germany

Dr. James M. Carpenter, American Museum of Natural History, New York, USA

Dr. David M. Claborn, Missouri State University, Springfield, USA

Dr. Kareen Schnabel, Marine Biologist, Wellington, New Zealand

Dr. Amazonas Chagas Júnior, Universidade Federal de Mato Grosso, Cuiabá, Brasil

Mr. Monsoon Jyoti Gogoi, Assam University, Silchar, Assam, India

Dr. Heo Chong Chin, Universiti Teknologi MARA (UiTM), Selangor, Malaysia

Dr. R.J. Shiel, University of Adelaide, SA 5005, Australia

Dr. Siddharth Kulkarni, The George Washington University, Washington, USA

Dr. Priyadarsanan Dharma Rajan, ATREE, Bengaluru, India

Dr. Phil Alderslade, CSIRO Marine And Atmospheric Research, Hobart, Australia

Dr. John E.N. Veron, Coral Reef Research, Townsville, Australia

Dr. Daniel Whitmore, State Museum of Natural History Stuttgart, Rosenstein, Germany.

Dr. Yu-Feng Hsu, National Taiwan Normal University, Taipei City, Taiwan

Dr. Keith V. Wolfe, Antioch, California, USA

Dr. Siddharth Kulkarni, The Hormiga Lab, The George Washington University, Washington,

D.C., USA

Dr. Tomas Ditrich, Faculty of Education, University of South Bohemia in Ceske

Budejovice, Czech Republic

Dr. Mihaly Foldvari, Natural History Museum, University of Oslo, Norway

Dr. V.P. Uniyal, Wildlife Institute of India, Dehradun, Uttarakhand 248001, India

Dr. John T.D. Caleb, Zoological Survey of India, Kolkata, West Bengal, India

Dr. Priyadarsanan Dharma Rajan, Ashoka Trust for Research in Ecology and the Environment

(ATREE), Royal Enclave, Bangalore, Karnataka, India

\section{Fishes}

Dr. Neelesh Dahanukar, IISER, Pune, Maharashtra, India

Dr. Topiltzin Contreras MacBeath, Universidad Autónoma del estado de Morelos, México

Dr. Heok Hee Ng, National University of Singapore, Science Drive, Singapore

Dr. Rajeev Raghavan, St. Albert's College, Kochi, Kerala, India

Dr. Robert D. Sluka, Chiltern Gateway Project, A Rocha UK, Southall, Middlesex, UK

Dr. E. Vivekanandan, Central Marine Fisheries Research Institute, Chennai, India

Dr. Davor Zanella, University of Zagreb, Zagreb, Croatia

Dr. A. Biju Kumar, University of Kerala, Thiruvananthapuram, Kerala, India

Dr. Akhilesh K.V., ICAR-Central Marine Fisheries Research Institute, Mumbai Research

Centre, Mumbai, Maharashtra, India

Dr. J.A. Johnson, Wildlife Institute of India, Dehradun, Uttarakhand, India

Amphibians

Dr. Sushil K. Dutta, Indian Institute of Science, Bengaluru, Karnataka, India

Dr. Annemarie Ohler, Muséum national d'Histoire naturelle, Paris, France

\section{Reptiles}

Dr. Gernot Vogel, Heidelberg, Germany

Dr. Raju Vyas, Vadodara, Gujarat, India

Dr. Pritpal S. Soorae, Environment Agency, Abu Dubai, UAE.

Prof. Dr. Wayne J. Fuller, Near East University, Mersin, Turkey

Prof. Chandrashekher U. Rivonker, Goa University, Taleigao Plateau, Goa. India

Dr. S.R. Ganesh, Chennai Snake Park, Chennai, Tamil Nadu, India

Dr. Himansu Sekhar Das, Terrestrial \& Marine Biodiversity, Abu Dhabi, UAE
Birds

Dr. Hem Sagar Baral, Charles Sturt University, NSW Australia

Dr. Chris Bowden, Royal Society for the Protection of Birds, Sandy, UK

Dr. Priya Davidar, Pondicherry University, Kalapet, Puducherry, India

Dr. J.W. Duckworth, IUCN SSC, Bath, UK

Dr. Rajah Jayapal, SACON, Coimbatore, Tamil Nadu, India

Dr. Rajiv S. Kalsi, M.L.N. College, Yamuna Nagar, Haryana, India

Dr. V. Santharam, Rishi Valley Education Centre, Chittoor Dt., Andhra Pradesh, India

Dr. S. Balachandran, Bombay Natural History Society, Mumbai, India

Mr. J. Praveen, Bengaluru, India

Dr. C. Srinivasulu, Osmania University, Hyderabad, India

Dr. K.S. Gopi Sundar, International Crane Foundation, Baraboo, USA

Dr. Gombobaatar Sundev, Professor of Ornithology, Ulaanbaatar, Mongolia

Prof. Reuven Yosef, International Birding \& Research Centre, Eilat, Israel

Dr. Taej Mundkur, Wetlands International, Wageningen, The Netherlands

Dr. Carol Inskipp, Bishop Auckland Co., Durham, UK

Dr. Tim Inskipp, Bishop Auckland Co, Durham, UK

Dr. V. Gokula, National College, Tiruchirappalli, Tamil Nadu, India

Dr. Arkady Lelej, Russian Academy of Sciences, Vladivostok, Russia

Dr. Simon Dowell, Science Director, Chester Zoo, UK

Dr. Mário Gabriel Santiago dos Santos, Universidade de Trás-os-Montes e Alto Douro,

Quinta de Prados, Vila Real, Portugal

Dr. Grant Connette, Smithsonian Institution, Royal, VA, USA

Dr. M. Zafar-ul Islam, Prince Saud Al Faisal Wildlife Research Center, Taif, Saudi Arabia

Mammals

Dr. Giovanni Amori, CNR - Institute of Ecosystem Studies, Rome, Italy

Dr. Anwaruddin Chowdhury, Guwahati, India

Dr. David Mallon, Zoological Society of London, UK

Dr. Shomita Mukherjee, SACON, Coimbatore, Tamil Nadu, India

Dr. Angie Appel, Wild Cat Network, Germany

Dr. P.O. Nameer, Kerala Agricultural University, Thrissur, Kerala, India

Dr. Ian Redmond, UNEP Convention on Migratory Species, Lansdown, UK

Dr. Heidi S. Riddle, Riddle's Elephant and Wildlife Sanctuary, Arkansas, USA

Dr. Karin Schwartz, George Mason University, Fairfax, Virginia.

Dr. Lala A.K. Singh, Bhubaneswar, Orissa, India

Dr. Mewa Singh, Mysore University, Mysore, India

Dr. Paul Racey, University of Exeter, Devon, UK

Dr. Honnavalli N. Kumara, SACON, Anaikatty P.O., Coimbatore, Tamil Nadu, India

Dr. Nishith Dharaiya, HNG University, Patan, Gujarat, India

Dr. Spartaco Gippoliti, Socio Onorario Società Italiana per la Storia della Fauna "Giuseppe

Altobello", Rome, Italy

Dr. Justus Joshua, Green Future Foundation, Tiruchirapalli, Tamil Nadu, India

Dr. H. Raghuram, The American College, Madurai, Tamil Nadu, India

Dr. Paul Bates, Harison Institute, Kent, UK

Dr. Jim Sanderson, Small Wild Cat Conservation Foundation, Hartford, USA

Dr. Dan Challender, University of Kent, Canterbury, UK

Dr. David Mallon, Manchester Metropolitan University, Derbyshire, UK

Dr. Brian L. Cypher, California State University-Stanislaus, Bakersfield, CA

Dr. S.S. Talmale, Zoological Survey of India, Pune, Maharashtra, India

Prof. Karan Bahadur Shah, Budhanilakantha Municipality, Kathmandu, Nepal

Dr. Susan Cheyne, Borneo Nature Foundation International, Palangkaraja, Indonesia

Dr. Hemanta Kafley, Wildlife Sciences, Tarleton State University, Texas, USA

\section{Other Disciplines}

Dr. Aniruddha Belsare, Columbia MO 65203, USA (Veterinary)

Dr. Mandar S. Paingankar, University of Pune, Pune, Maharashtra, India (Molecular)

Dr. Jack Tordoff, Critical Ecosystem Partnership Fund, Arlington, USA (Communities)

Dr. Ulrike Streicher, University of Oregon, Eugene, USA (Veterinary)

Dr. Hari Balasubramanian, EcoAdvisors, Nova Scotia, Canada (Communities)

Dr. Rayanna Hellem Santos Bezerra, Universidade Federal de Sergipe, São Cristóvão, Brazil

Dr. Jamie R. Wood, Landcare Research, Canterbury, New Zealand

Dr. Wendy Collinson-Jonker, Endangered Wildlife Trust, Gauteng, South Africa

Dr. Rajeshkumar G. Jani, Anand Agricultural University, Anand, Gujarat, India

Dr. O.N. Tiwari, Senior Scientist, ICAR-Indian Agricultural Research Institute (IARI), New

Delhi, India

Dr. L.D. Singla, Guru Angad Dev Veterinary and Animal Sciences University, Ludhiana, India

Dr. Rupika S. Rajakaruna, University of Peradeniya, Peradeniya, Sri Lanka

Dr. Bahar Baviskar, Wild-CER, Nagpur, Maharashtra 440013, India

Reviewers 2018-2020

Due to pausity of space, the list of reviewers for $2018-2020$ is available online.

The opinions expressed by the authors do not reflect the views of the Journal of Threatened Taxa, Wildlife Information Liaison Development Society, Zoo Outreach Organization, or any of the partners. The journal, the publisher, the host, and the partners are not responsible for the accuracy of the political boundaries shown in the maps by the authors.

Journal of Threatened Taxa is indexed/abstracted in Bibliography of Systematic Mycology, Biological Abstracts, BIOSIS Previews, CAB Abstracts, EBSCO, Google Scholar, Index Copernicus, Index Fungorum, JournalSeek, National Academy of Agricultural Sciences, NewJour, OCLC WorldCat, SCOPUS, Stanford University Libraries, Virtual Library of Biology, Zoological Records.

NAAS rating (India) 5.64
Print copies of the Journal are available at cost. Write to:

The Managing Editor, JoTT,

c/o Wildlife Information Liaison Development Society,

No. 12, Thiruvannamalai Nagar, Saravanampatti - Kalapatti Road,

Saravanampatti, Coimbatore, Tamil Nadu 641035, India

ravi@threatenedtaxa.org 


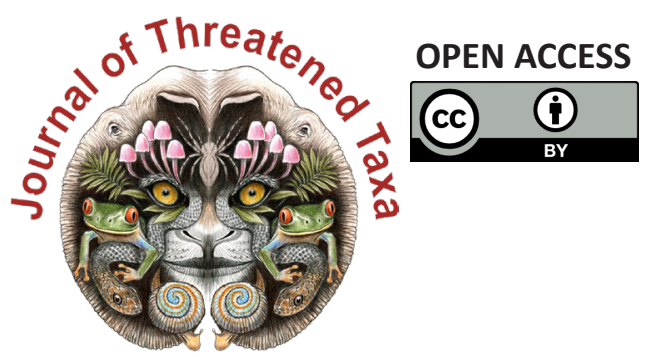

www.threatenedtaxa.org

The Journal of Threatened Taxa (JoTT) is dedicated to building evidence for conservation globally by publishing peer-reviewed articles online every month at a reasonably rapid rate at www.threatenedtaxa.org. All articles published in JoTT are registered under Creative Commons Attribution 4.0 International License unless otherwise mentioned. JoTT allows allows unrestricted use, reproduction, and distribution of articles in any medium by providing adequate credit to the author(s) and the source of publication.

\section{ISSN $0974-7907$ (Online) | ISSN $0974-7893$ (Print)}

\section{January 2022 | Vol. 14 | No. 1 | Pages: 20311-20538 \\ Date of Publication: 26 January 2022 (Online \& Print) DOI: 10.11609/jott.2022.14.1.20311-20538}

Articles

Estimating the completeness of orchid checklists and atlases: a case study from southern Italy

- Antonio Croce, Pp. 20311-20322

A floristic survey across three coniferous forests of Kashmir Himalaya, India - a checklist

- Ashaq Ahmad Dar, Akhtar Hussain Malik \& Narayanaswamy Parthasarathy, Pp. 20323-20345

Associations of butterflies across different forest types in Uttarakhand, western Himalaya, India: implications for conservation planning

- Arun Pratap Singh, Pp. 20346-20370

Comparison of bird diversity in protected and non-protected wetlands of western lowland of Nepal

- Jagan Nath Adhikari, Janak Raj Khatiwada, Dipendra Adhikari, Suman Sapkota, Bishnu Prasad Bhattarai, Deepak Rijal \& Lila Nath Sharma, Pp. 20371-20386

Local hunting practices and perceptions regarding the distribution and ecological role of the Large Flying Fox (Chiroptera: Pteropodidae: Pteropus vampyrus) in western Sarawak, Malaysian Borneo

- Jayasilan Mohd-Azlan, Joon Yee Yong, Nabila Norshuhadah Mohd Hazzrol, Philovenny Pengiran, Arianti Atong \& Sheema Abdul Aziz, Pp. 20387-20399

\section{Communications}

Macrolichens of Mathikettan Shola National Park, Western Ghats: a preliminary investigation with some new records

- Aswathi Anilkumar, Stephen Sequeira, Arun Christy \& S.M. Arsha, Pp. 20400-20405

New distribution record of globally threatened Ocean Turf Grass Halophila beccarii Ascherson, 1871 from the North Andaman Islands highlights the importance of seagrass exploratory surveys

- Swapnali Gole, Prasad Gaidhani, Srabani Bose, Anant Pande, Jeyaraj Antony Johnson \& Kuppusamy Sivakumar, Pp. 20406-20412

An inventory of new orchid (Orchidaceae) records from Kozhikode, Kerala, India - M. Sulaiman, C. Murugan \& M.U. Sharief, Pp. 20413-20425

Abundance and spatial distribution analyses of Stemonoporus moonii Thwaites (Dipterocarpaceae) - a critically endangered species endemic to Sri Lanka - K.A.M.R.P. Atapattu, H.D.D.C.K. Perera, H.S. Kathriarachchi \& A.R. Gunawardena, Pp. 20426-20432

Plant diversity of Point Calimere Wildlife Sanctuary and fodder species grazed by the Blackbuck Antilope cervicapra L.

- Ashutosh Kumar Upadhyay, A. Andrew Emmanuel, Ansa Sarah Varghese \&

D. Narasimhan, Pp. 20433-20443

Raptors observed (1983-2016) in National Chambal Gharial Sanctuary: semi-arid biogeographic region suggestions for parametric studies on ecological continuity in Khathiar-Gir Ecoregion, India

- L.A.K. Singh, R.K. Sharma \& Udayan Rao Pawar, Pp. 20444-20460

Nesting success of Sharpe's Longclaw (Macronyx sharpei Jackson, 1904) around the grasslands of lake Ol'bolossat Nyandarua, Kenya

- Hamisi Ann Risper, Charles M. Warui \& Peter Njoroge, Pp. 20461-20468

Population, distribution and diet composition of Smooth-coated Otter Lutrogale perspicillata Geoffroy, 1826 in Hosur and Dharmapuri Forest Divisions, India - Nagarajan Baskaran, Raman Sivaraj Sundarraj \& Raveendranathanpillai Sanil, Pp. 20469-20477

Utilization of home garden crops by primates and current status of human-primate interface at Galigamuwa Divisional Secretariat Division in Kegalle District, Sri Lanka

- Charmalie Anuradhie Dona Nahallage, Dahanakge Ayesha Madushani Dasanayake, Dilan Thisaru Hewamanna \& Dissanayakalage Tharaka Harshani Ananda, Pp. 2047820487
Revival of Eastern Swamp Deer Rucervus duvaucelii ranjitsinhi (Groves, 1982) in Manas National Park of Assam, India

- Nazrul Islam, Aftab Ahmed, Rathin Barman, Sanatan Deka, Bhaskar Choudhury, Prasanta Kumar Saikia \& Jyotishman Deka, Pp. 20488-20493

Trypanosoma evansi infection in a captive Indian Wolf Canis lupus pallipes - molecular diagnosis and therapy

- Manojita Dash, Sarat Kumar Sahu, Santosh Kumar Gupta, Niranjana Sahoo \& Debarat Mohapatra, Pp. 20494-20499

View Point

COVID-19 and civil unrest undoing steady gains in karst conservation and herpetological research in Myanmar, and an impediment to progress - Evan S.H. Quah, Lee L. Grismer, Perry L. Wood, Jr., Aung Lin \& Myint Kyaw Thura, Pp. 20500-20502

\section{Short Communications}

Morphological characterization and mt DNA barcode of a tiger moth species, Asota ficus (Fabricius, 1775) (Lepidoptera: Noctuoidea: Erebidae: Aganainae) from India - Aparna Sureshchandra Kalawate, K.P. Dinesh \& A. Shabnam, Pp. 20503-20510

Distribution of Smooth-coated Otters Lutrogale perspicillata (Mammalia: Carnivora: Mustelidae): in Ratnagiri, Maharashtra, India

- Swanand Patil \& Kranti Yardi, Pp. 20511-20516

Wildlife at the crossroads: wild animal road kills due to vehicular collision on a mountainous highway in northwestern Himalayan region

- Muzaffar A. Kichloo, Asha Sohil \& Neeraj Sharma, Pp. 20517-20522

Notes

Robiquetia gracilis (Lindl.) Garay-a new record to the flora of Anamalai Hills, Tami Nadu, India

- B. Subbaiyan, V. Ganesan, P.R. Nimal Kumar \& S. Thangaraj Panneerselvam, Pp. 20523-20525

Ipomoea laxiflora H.J. Chowdhery \& Debta (Convolvulaceae): new records for the Western Ghats and semiarid regions

- Sachin M. Patil, Ajit M. Vasava, Vinay M. Raole \& Kishore S. Rajput, Pp. 20526-20529

Counting the cost: high demand puts Bunium persicum (Boiss.) B.Fedtsch. in jeopardy

- Monika Sharma, Manisha Mathela, Rupali Sharma, Himanshu Bargali, Gurinderjit S Goraya \& Amit Kumar, Pp. 20530-20533

First record of Parasitic Jaeger Stercorarius parasiticus (Aves: Charadriiformes: Stercorariidae) from inland freshwater Inle Lake, Myanmar

- Sai Sein Lin Oo, Myint Kyaw, L.C.K. Yun, Min Zaw Tun, Yar Zar Lay Naung, Soe Naing Aye \& Swen C. Renner, Pp. 20534-20536

\section{Book Review}

Capparis of India

- V. Sampath Kumar, Pp. 20537-20538
Publisher \& Host
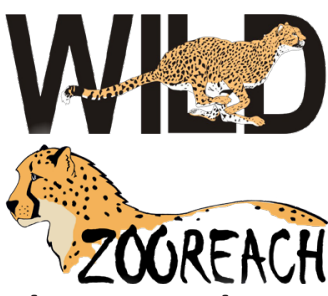

Threatened Taxa 